\title{
Presence of phytoplasma infections in papaya (Carica papaya L.) Plants in Uttar Pradesh, India
}

\author{
ANCHAL RANI ${ }^{1}$, PRAGATI MISRA ${ }^{* 1}$, JITENDRA SINGH ${ }^{2}$, PANKAJ KUMAR ${ }^{2}$, ROSY RANI $^{1}$ AND PRADEEP \\ SHUKLA $^{1}$ \\ ${ }^{1}$ Sam Higginbottom Institute of Agriculture, Technology and Sciences, ALLAHABAD (U.P.) INDIA \\ ${ }^{2}$ College of Biotechnology, Sardar Vallabhbhai Patel University of Agriculture and Technology, MEERUT (U.P.) INDIA
}

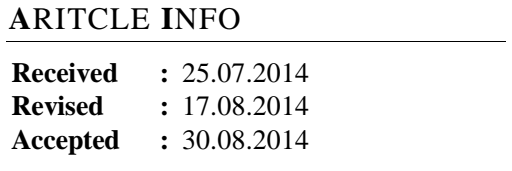

\section{KEY WORDS :}

Papaya, Phytoplasma, Curl apical necrosis, PCR

*Corresponding author:

Email: pragati.misra@shiats.edu.in

\begin{abstract}
During survey of papaya fields in Meerut, severe symptoms of leaf yellowing, intervenial chlorosis, and curl apical necrosis were observed in approximately 25 per cent of plants in each of the papaya fields. DNA extracted from leaf, midrib and bark of symptomatic and healthy plants of papaya were preceded with universal primer pairs. Expected $\sim 1600 \mathrm{bp}$ fragments were amplified with primer pair P1/Tint in diseased plants. Infection of phytoplasma disease in papaya plants was confirmed by the PCR.
\end{abstract}

How to view point the article : Rani, Anchal, Misra, Pragati, Singh, Jitendra, Kumar, Pankaj, Rani, Rosy and Shukla, Pradeep (2014). Presence of phytoplasma infections in papaya (Carica papaya L.) Plants in Uttar Pradesh, India. J. Plant Protec., 7(2) : 401-404. 